\title{
Pengembangan User Interface (UI) Dan User Experience (UX) Aplikasi Cashoop Untuk Pengelolaan Keuangan Pribadi
}

\author{
Furgandini Rencang Pambajeng(12018073) ${ }^{1}$, Ardiansyah(0523077902) ${ }^{2}$ \\ Teknik Informatika Universitas Ahmad Dahlan, Jl. Ringroad Selatan, Bantul, Yogyakarta 55191, Indonesia \\ ${ }^{1}$ furgandinirencang@gmail.com; ${ }^{2}$ ardiansyah@tif.uad.ac.id
}

\begin{abstract}
ABSTRAK
Pengelolaan finansial yang baik sangat membantu individu maupun keluarga dalam mengambil keputusan-keputusan finansialnya. Saat ini aplikasi pengelolaan keuangan juga marak seperti MyFamily Accounting, Amplop.In dan NgaturDuit. Akan tetapi ketiga aplikasi tersebut memiliki beberapa kelemahan antara lain masih dalam versi desktop dan web saja. Dari hasil analisis aplikasi sebelumnya masih berbasis desktop yang dikoneksikan dengan Pocket PC. Aplikasi ini memiliki kelemahan dari sisi teknologi yang sudah lawas dan sangat jarang digunakan yaitu Pocket PC dan juga aplikasi desktop yang sudah ditinggalkan. Dengan meninjau masalah ini dibutuhkan suatu solusi yaitu merancang desain user interface dan user experience aplikasi Cashoop yang membantu para pengguna untuk mengelola keuangan pribadinya dengan lebih efektif, efisien dan memuaskan dari sisi usability.

Metodologi yang digunakan dalam penelitian ini yaitu melakukan pengumpulan data menggunakan mrtode kuisioner. Kemudian dilakukan analisis data, deskripsi kebutuhan sistem dan pembuatan UML (Unified Modelling Language). Tahap selanjutnya adalah perancangan desain user interface dan user experience aplikasi cashoop, dan pengujian user interface dan user experience ini dengan menggunakan metode pengujian Usability Post Task (SEQ) dan Post Study (SUS).

Berdasarkan hasil pengukuran desain user interface dan user experience aplikasi cashoop berbasis mobile yang dikembangan sesuai dengan pengujian usability terbukti membantu dalam proses pengembangan dan hasil pengukuran tingkat keberhasilan pengguna sebesar $100 \%$, pengukuran kemudahan penguna dengan nilai rata-rata skor SEQ 5,1 (mudah) dan pengukuran kepuasan pengguna dengan nilai rata-rata SUS responden 71,08 (Acceptable).
\end{abstract}

Ciptaan disebarluaskan di bawah lisensi CC-BY-SA.

Kata kunci: Pengelolaan Keuangan, Personal Finance, User Interface, User Experience, usability

\section{Pendahuluan}

Personal finance merupakan suatu bidang ilmu yang dilakukan oleh seseorang atau sebuah keluarga dalam rangka mengelola, menganggarkan (budgeting), menyimpan (saving) dan mengeluarkan (spending). Sumber -sumber finansial yang diperoleh selama ini dengan konsekuensi terjadinya berbagai macam risiko finansial dan dampak kehidupannya kelak di masa depan (Ardiansyah, 2012)[1] .

Pengelolaan finansial yang baik tidak hanya menjadi kebutuhan bagi perusahaan maupun organisasi saja. Sebagai bagian terkecil sebuah organisasi, baik individu maupun keluarga juga memiliki kebutuhan untuk dapat mengelola finansialnya sendiri. Adanya pengelolaan finansial yang baik tentu sangat membantu dalam mengambil keputusan-keputusan finansial. Masalah yang dihadapi individu dan keluarga saat ini adalah tingkat literasi finansial yang masih rendah. Akibatnya banyak yang melakukan analisa hingga pengambilan keputusan dengan hanya menggunakan perasaan semata, tanpa didasarkan pada data dan fakta historis finansial. Hal ini tentu saja akan membawa dampak serius terhadap keberlangsungan finansialnya di masa depan apabila keputusan yang diambil tersebut ternyata salah atau tidak tepat (Ardiansyah, 2012)[1]. 
Saat ini sudah ada beberapa strategi dan upaya yang dilakukan oleh pemerintah dan pihak swasta untuk meningkatkan kemampuan mengelola keuangan. Seperti yang dilakukan oleh Citibank dalam bentuk pertunjukan teater dan komik pengelolaan keuangan. Disusul bank Permata dan CIMB Niaga menggunakan strategi melalui permainan (games) di komputer yang berisi simulasi pengelolaan uang sehari-hari. Di sisi lain, aplikasi dan tools berupa piranti lunak untuk pengelolaan keuangan pribadi juga marak seperti MyFamily Accounting, Amplop.In dan NgaturDuit. Akan tetapi ketiga aplikasi tersebut memiliki beberapa kelemahan yaitu antara lain masih dalam versi desktop dan web saja, tidak menerapkan konsep akuntansi double-entry, belum memiliki tracking investasi dan aset, manajemen hutang dan rencana finansial masa depan.

Dari penelitian sebelumnya yang menghasilkan sebuah aplikasi desktop yang dikoneksikan dengan Pocket PC (lihat gambar 1)[2]. Penelitian ini memiliki kelemahan dari sisi teknologi yang sudah lawas dan sangat jarang digunakan yaitu Pocket PC dan juga aplikasi desktop yang sudah ditinggalkan karena saat ini sudah beralih berbasis web.

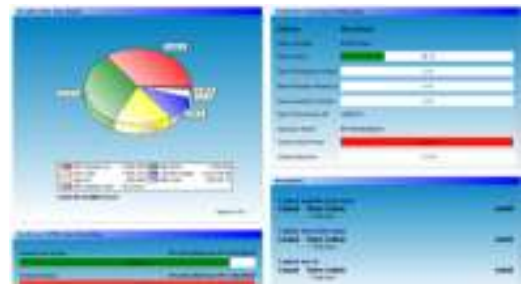

Gambar 1 Sistem aplikasi MyFamily Accounting (Ardiansyah \& Sujatmiko, 2007)

Seiring dengan perkembangan teknologi aplikasi yang beralih berbasis web, maka pengembangan aplikasi keuangan pribadi juga mulai mengembangkan aplikasinya ke basis web. Pengembangan ini dimulai oleh Prayinda (2014) dengan mengimplementasikan web responsive[3]. Walaupun web memberikan fleksibilitas dari sisi platform yang netral, akan tetapi menyediakan versi web saja tidak memberikan fleksibilitas dalam mencatat transaksi secara mobile. Karena kebiasaan masyarakat saat ini yang sudah terbiasa dalam keadaan bergerak dan berpindah-pindah. Apalagi hampir semua transaksi keuangan rutin individu/keluarga berada di luar rumah/ruang. Contoh membeli makanan, belanja rutin, pengisian BBM, membeli pakaian dan lain sebagainya.

\section{Kajian Pustaka}

Kajian terdahulu mengacu pada Penelitian yang dilakukan oleh Ardiansyah (2012) tentang Analisis Pengambilan Keputusan berbasis Personal Finance Information System [1]. Aplikasi keuangan ini berbasis desktop yang dikoneksikan dengan Pocket PC. Aplikasi ini memiliki fitur yang diperlukan oleh pengguna secara langsung seperti menampilkan laporan keuangan bulanan, pencatatan transaksi harian serta perhitungan piutang dan aset yang dimiliki.

Penelitian yang dilakukan oleh Rochim et al (2011) tentang Aplikasi Pengelolaan Keuangan Perusahaan menyebutkan permasalahan yang terjadi adalah pembukuan kas masuk dan kas keluar yang masih manual menyebabkan pencatatan penerimaan dan pengeluaran kas menjadi tidak efektif [3]. Berdasarkan permasalahan tersebut, aplikasi ini dibuat untuk membantu perusahaan, dalam hal ini PT. Jala Prokreasi Surakarta, dalam mengelola kas perusahaan, pembuatan jurnal umum dan laporan keuangan.

\section{User Interface}

User Interface merupakan salah satu bagian paling penting dalam sistem komputer karena user interface berhubungan dengan pengguna, dapat dilihat, dapat didengar, dan dapat disentuh [4].

2. User Experience

User Experience (UX) bukan merupakan cara kerja dari suatu produk atau jasa melainkan User Experience merupakan cara kerja diluar, dimana seseorang datang dan berhadapan langsung [5].

\section{Usability}


Usability adalah atribut kualitas yang menjelaskan atau mengukur seberapa mudah penggunaan suatu antar muka (interface). Kata "usability" juga merujuk pada metode untuk meningkatkan kemudahan pemakaian selama proses perancangan / desain.

Berikut adalah pengujian yang akan dilakukan :

1) Pengukuran Efektifitas

Menentukan skenario dengan kriteria keberhasilan yang jelas dan pengguna harus mencoba aplikasi. Contoh kasus : pengguna melakukan login aplikasi, jika pengguna menyelesaikan task dengan sukses, maka kita memberi pengguna dengan nilai 1 dan jika pengguna gagal, maka kita memberi nilai 0 (Sauro, 2011)[6].

2) Pengukuran Kemudahan

Metode yang digunakan yaitu SEQ (Single Ease Question). Single Ease Question(SEQ) adalah skala rating 7-point untuk menilai seberapa sulit pengguna mengenai sebuah task. Ini diberikan segera setelah pengguna mencoba tugas dalam usability test (Sauro \& Lewis, 2012)[8].

Skala likert 7 level sendiri mempunyai 2 ujung kutub skala yaitu sangat sulit pada sisi kiri dan sangat mudah pada sisi kanan. Jadi di dalam butir (item) Skala Likert dijabarkan antara 2 ujung kutub tersebut ada 7 skala. Ketika diuraikan menjadi sangat sulit, sulit, cukup sulit, cukup, cukup mudah, mudah, sangat mudah.

3) Pengukuran Efisiensi

Menurut ISO 9241-11 efisiensi dapat diukur dari segi waktu tugas yaitu waktu yang diperlukan peserta untuk berhasil menyelesaikan tugas.

Waktu yang dibutuhkan untuk menyelesaikan tugas dapat dihitung dengan mengurangi waktu selesai responden mengerjakan task dikurangi waktu mulainya.

4) Pengukuran Kepuasan

Pengujian yang dilakukan setelah user menggunakan sistem secara menyeluruh dengan metode SUS (Software Usability Scale). Pengujian ini digunakan untuk mengukur kemudahan yang dirasakan oleh user setelah menyelesaikan semua skenario / task yang diberikan (Sauro \& Lewis, 2012)[7].

Perhitungan SUS menurut Sauro (2011) [6] adalah sebagai berikut :

a. Untuk item ganjil: kurangi satu dari respon pengguna.

b. Untuk item genap: kurangi tanggapan pengguna dari 5 .

c. Semua skala nilai 0-4 (dengan empat menjadi respon paling positif).

d. Menjumlahkan tanggapan dikonversi untuk setiap pengguna dan kalikan jumlah total dengan 2,5. Ini mengubah rentang nilai yang mungkin dari 0 sampai 100 bukannya 0-40.

\section{Metodologi Penelitian}

\subsection{Metode Pengumpulan Data}

1. Wawancara

Metode wawancara dilakukan dengan mengadakan tanya jawab dengan pakar ahli keuangan atau peneliti aplikasi keuangan keluarga terdahulu.

2. Kuisioner

Metode ini dilakukan dengan menyebar kuisioner kepada responden dengan tujuan untuk memperoleh informasi secara langsung dan mengenai masalah dari topik yang diteliti. Kuisioner yang diberikan berupa post task dan post study yang digunakan untuk mengukur kemudahan yang 
dirasakan pengguna setelah menyelesaikan semua task dengan menggunakan metode $S E Q$ (Single Ease Question) dan pengukuran kepuasan yang berisi 10 pertanyaan dengan menggunakan metode SUS (System Usability Scale).

\subsection{Analisis Kebutuhan}

1. Kebutuhan User

Kegiatan dalam tahap ini adalah menganalisis kebutuhan user untuk membangun perancangan user experience dan user interface pada aplikasi Cashoop untuk pengelolaan keuangan pribadi.

2. Kebutuhan Sistem

a. Kebutuhan Fungsional

b. Kebutuhan Non Fungsional

\subsection{Perancangan Sistem}

1. Use Case Diagram

Use Case Diagram menggambarkan interaksi antara aktor-aktor dengan sistem yang dibangun, serta menggambarkan fungsionalitas yang dapat diberikan sistem kepada user.

2. Activity Diagram

Activity diagram menggambarkan aliran aktifitas dalam sistem yang sedang dirancang, bagaimana masing-masing alir berawal, decision yang mungkin terjadi, dan bagaimana mereka berakhir.

\subsection{Desain UI dan UX}

1. Desain Konseptual

a. Model Interaksi

Model interaksi yang digunakan berbasis aktivitas. Model interaksi pada aplikasi yang akan dirancang yaitu memberikan instruksi yang digunakan pengguna meliputi anggota melakukan pencatatan anggaran keuangan dan mengetahui transaksi pengeluaran dan pemasukan dalam satu bulan.

b. Paradigma Interaksi

Paradigma interaksi dapat dibuat dengan menggunakan paradigma yang berbasis Ubiquitous Computing dimana Ubiquitous Computing digunakan di mana saja. Seperti halnya perancangan yang akan dilakukan oleh peneliti yaitu merancang desain user interface dan user experience aplikasi mobile.

c. Arsitektur Informasi

Pada penelitian ini arsitektur informasi dilakukan dengan memberikan infromasi yang tepat tekait beberapa struktur menu yang akan di tata secara tepat sehingga pengguna dapat menggunakan menu aplikasi ini dengan baik .

2. Desain Fisik

a. Paper Prototyping

Penggunaan paper prototyping ini sangat serbaguna untuk membuat rancangan mentah untuk mendesain tampilan serta tata letak dari aplikasi yang akan dibangun sebelum perancangan menggunakan aplikasi.

b. Visual Mock Up

Pada tahap visual mock up ini digunakan tools justinmind prototype untuk membuat mock up aplikasi cashoop berbasis mobile.

c. Desain Interaksi Visual

Perancanan User Interface dan User Experience yang dikembangkan, nantinya akan digunakan untuk diimplementasikan pada desain interaksi visual atau aplikasi yang sudah berjalan. Untuk pengembangan selanjutnya agar aplikasi berfungsi sepenuhnya, makan dibutuhkan tools untuk mendevelop seperti HTML, CSS, JavaScript dan Android Studio.

\subsection{Pengujian Usability}

Pengujian yang di lakukan menggunakan pengujian post task dan post study. 


\section{Hasil Dan Pembahasan}

\subsection{Hasil Pengumpulan Data}

- Data Hasil Wawancara

a. User harus terlebih dahulu mendaftar sebagai anggota agar bisa mengakses aplikasi cashoop.

b. Anggota dapat melihat transaksi pemasukan dan pengeluaran yang telah dilakukan dalam satu bulan

- Data Hasil Kuisioner

Penyebaran kuisioner dilakukan kepada 30 responden yang memanfaatkan aplikasi cashoop sebagai media untuk mengelola keuangan. Adapun data yang didapat sebagai berikut :

a. 3 responsen berstatus sebagai mahasiswa dan 27 lainnya adalah umum.

b. Berdasarkan data yang diperoleh dari penyebaran kuisioner didapatkan bahwa 50\% responden belum memahami tentang aplikasi pengelolaan keuangan.

c. Ketertarikan responden untuk mengelola keuangan berbasis mobile, karena mudah dibawa kemana saja dan bisa diakses kapan pun asalkan tersedia jaringan internet.

d. $90 \%$ responden merasa tertarik untuk menggunakan aplikasi cashoop guna untuk mempermudah mereka dalam mengelola keuangan pribadinya.

\subsection{Hasil Analisis Kebutuhan}

1. Kebutuhan User

a. Masyarakat umum melakukan registrasi untuk menjadi anggota cashoop.

b. Anggota melakukan login cashoop.

c. Anggota melakukan pencatatan pendapatan ( income ).

d. Anggota melakukan pencatatan pengeluaran (Spending).

e. Anggota melakukan pencatatan kekayaan.

f. Anggota melakukan pencatatan hutang.

g. Anggota melihat data transaksi pendapatan dan pengeluaran.

h. Anggota melihat kekayaan aset.

i. Anggota melihat kekayaan hutang.

j. Anggota melihat data pendapatan yang melebihi pengeluaran ataupun pengeluaran yang melebihi pendapatan.

k. Anggota melakukan pencatatan anggaran pemasukan (income).

1. Anggota melakukan pencatatan anggaran penyimpanan keuangan (saving).

m. Anggota melakukan pencatatan anggaran bayar hutang.

n. Anggota melakukan pencatatan anggaran pengeluaran (spending)

o. Anggota melakukan logout.

2. Kebutuhan Sistem

a. Kebutuhan Fungsional

1) Registrasi

a) Sistem akan merekam atau menyimpan username dan password registrasi.

b) Sistem akan validasi username dan password registrasi, bila ada user yang registrasi dengan username yang sama.

2) Login

Sistem akan mengijinkan user masuk kedalam sistem.

3) Akun Income

a) Sistem akan menampilkan form input data pemasukan.

b) Sistem akan menyimpan data pemasukan yang telah diinput.

4) Akun Spending

a) Sistem akan menampilkan form input data pengeluaran.

b) Sistem akan menyimpan data pengeluaran yang telah diinput.

5) Akun Aset

a) Sistem akan menampilkan form input data aset.

b) Sistem akan menyimpan data aset yang telah diinput.

6) Akun Hutang 
a) Sistem akan menampilkan form input data hutang.

b) Sistem akan menyimpan data hutang yang telah diinput.

7) Transaksi

Sistem akan menampilkan data pemasukan dan pengeluaran yang telah dilakukan dalam sebulan.

8) Kekayaan Aset

Sistem akan menampilkan data kekayaan aset yang dimiliki oleh anggota.

9) Kekayaan Hutang

Sistem akan menampilkan data kekayaan hutang yang dimiliki oleh anggota.

10)Surplus / Defisit

Sistem akan menampilkan data pendapatan yang melebihi pengeluaran ataupun pengeluaran yang melebihi pendapatan.

11)Anggaran Income

a) Sistem akan menampilkan form input data anggaran pemasukan.

b) Sistem akan menyimpan data anggaran pemasukan yang telah diinput.

12)Anggaran Saving

a) Sistem akan menampilkan form input data anggaran saving.

b) Sistem akan menyimpan data anggaran saving yang telah diinput.

13)Anggaran Bayar Hutang

a) Sistem akan menampilkan form input data anggaran bayar hutang.

b) Sistem akan menyimpan data anggaran bayar hutang yang telah diinput.

14)Anggaran Spending

a) Sistem akan menampilkan form input data anggaran pengeluaran.

b) Sistem akan menyimpan data anggaran pengluaran yang telah diinput.

15)Logout

Sistem akan mengijinkan user untuk keluar dari sistem.

b. Kebutuhan Non Fungsional

1) Operasional

a) Aplikasi hanya dapat diakses dengan menggunakan internet.

b) Sistem dapat berjalan di smartphone

2) Security

Semua password user terlindungi oleh enkripsi.

\subsection{Hasil Perancangan Sistem}

\section{Use Case Diagram}

Untuk mendapatkan gambaran mengenai sistem yang akan dibuat maka digunakan proses dan data model dari sistem yang di modelkan dengan use case diagram. Dengan use case diagram ini dapat diketahui fungsi yang digunakan oleh sistem. Dibawah ini merupakan gambaran dari sistem yang akan dibuat : 


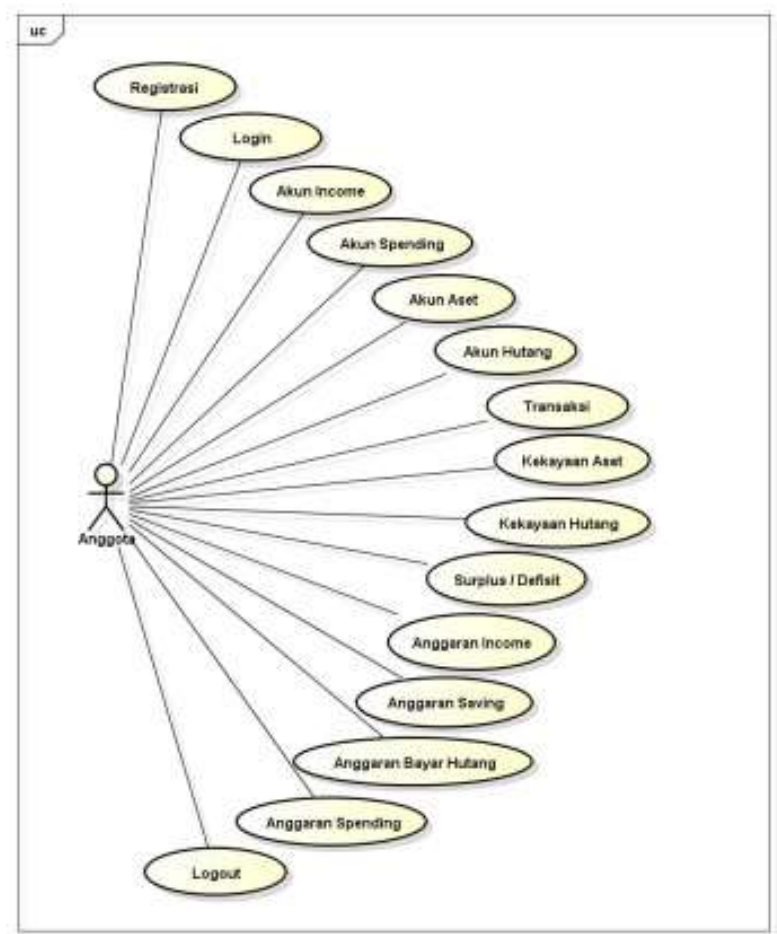

Gambar 2 Use Case Diagram

Gambar use case diagram menjelaskan bahwa anggota sebagai aktor dapat melakukan registrasi, login, mencatat data pemasukan pada akun income, mencatat data pengeluaran pada akun spending, mencatat data kekayaan pada akun aset, mencatat banyaknya hutang pada akun hutang, melihat data transaksi pendapatan dan pengeluaran dalam satu bulan, melihat data kekayaan aset, data melihat kekayaan hutang, melihat data pengeluaran lebih banyak dari pendapatan atau pendapatan lebih banyak dari pengeluaran pada surplus / defisit, anggaran income, anggaran saving, anggaran bayar hutang, anggaran spending, logout sistem aplikasi Cashoop.

\subsection{Hasil Desain UI dan UX}

\section{Desain Fisik}

a. Desain Visual Mockup

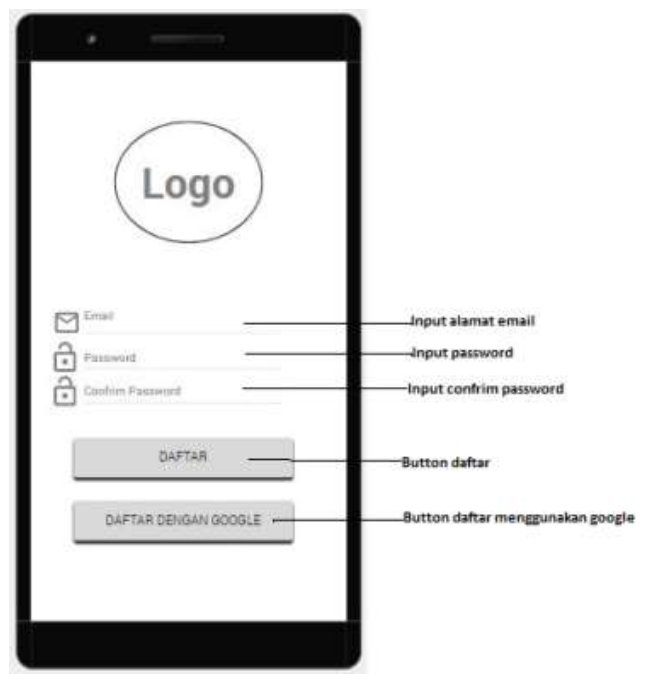

Gambar 3 Mock Up Pendaftaran 
Rancangan visual pada gambar 3 adalah menu registrasi yang akan muncul setelah pengguna memilih menu daftar sekarang pada menu login. Fungsi-fungsi yang digunakan dalam desain diatas adalah ellipse untuk logo aplikasi, icon email outline dan input text untuk menginput alamat email, icon lock open outline dan input text untuk menginput password dan confrim password, button daftar untuk mendaftar menjadi anggota Cashoop.

b. Desain Interaksi Visual

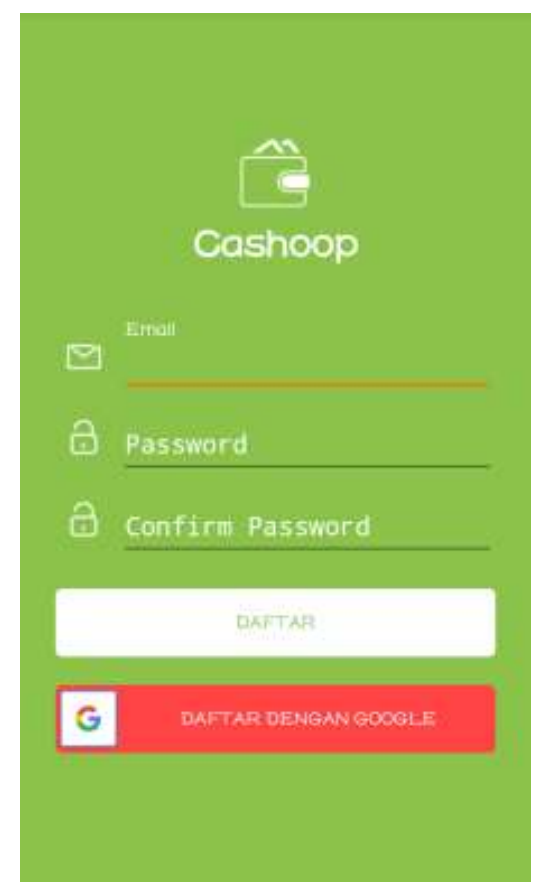

Gambar 4 Tampilan Pendaftaran

Gambar 4 adalah tampilan registrasi yang akan muncul setelah pengguna memilih menu daftar sekarang pada menu login, registrasi bisa dilakukan secara manual pada aplikasi Cashoop atau menggunakan akun google.

\subsection{Hasil Pengujian Usability}

\section{Pengukuran Efektifitas}

Pengujian dilakukan dengan memberikan skenario yang akan dijadikan acuan oleh responden dalam mengerjakan task. Model dari task yang akan diberikan seperti pada tabel 1 berikut:

Tabel 1 Tugas Pengujian

\begin{tabular}{|c|c|c|}
\hline $\begin{array}{l}\text { No } \\
\text { Fungsi }\end{array}$ & Fungsi & Task / Tugas \\
\hline F1 & Registrasi & $\begin{array}{l}\text { Melakukan registrasi dengan menggunakan alamat email, } \\
\text { mengisi identitas anggota serta password untuk login }\end{array}$ \\
\hline $\mathrm{F} 2$ & Login & $\begin{array}{l}\text { Melakukan login untuk masuk dalam aplikasi dengan } \\
\text { memasukkan alamat email dan password }\end{array}$ \\
\hline F3 & $\begin{array}{l}\text { Akun } \\
\text { Income }\end{array}$ & Melakukan pencatatan pendapatan pada menu akun income \\
\hline F4 & $\begin{array}{l}\text { Akun } \\
\text { Spending }\end{array}$ & Melakukan pencatatan pengeluaran pada menu akun spending \\
\hline F5 & Akun Aset & $\begin{array}{c}\text { Melakukan pencatatan aset awal / kekayaan awal pada menu } \\
\text { akun aset }\end{array}$ \\
\hline F6 & $\begin{array}{l}\text { Akun } \\
\text { Hutang }\end{array}$ & Melakukan pencatatan hutang pada menu akun hutang \\
\hline
\end{tabular}




\begin{tabular}{|c|c|c|}
\hline F7 & Transaksi & Melihat data pendapatan dan pengeluaran dalam satu bulan \\
\hline F8 & $\begin{array}{l}\text { Kekayaan } \\
\text { Aset }\end{array}$ & Melihat data kekayaan yang dimiliki \\
\hline F9 & $\begin{array}{l}\text { Kekayaan } \\
\text { Hutang }\end{array}$ & Melihat data hutang yang dimiliki \\
\hline F10 & $\begin{array}{l}\text { Surplus / } \\
\text { Defisit }\end{array}$ & $\begin{array}{l}\text { Melihat data pendapatan yang melebihi pengeluaran ataupun } \\
\text { pengeluaran yang melebihi pendapatan }\end{array}$ \\
\hline F11 & $\begin{array}{l}\text { Anggaran } \\
\text { Income }\end{array}$ & $\begin{array}{l}\text { Melakukan pencatatan anggaran pendapatan keuangan pada } \\
\text { menu anggaran Income }\end{array}$ \\
\hline F12 & $\begin{array}{l}\text { Anggaran } \\
\text { Saving }\end{array}$ & $\begin{array}{l}\text { Melakukan pencatatan anggaran penyimpanan keuangan pada } \\
\text { menu anggaran saving }\end{array}$ \\
\hline F13 & $\begin{array}{l}\text { Anggaran } \\
\text { Bayar } \\
\text { Hutang }\end{array}$ & $\begin{array}{l}\text { Melakukan pencatatan anggaran bayar hutang yang dimiliki } \\
\text { pada menu anggaran bayar hutang }\end{array}$ \\
\hline F14 & $\begin{array}{l}\text { Anggaran } \\
\text { Spending }\end{array}$ & $\begin{array}{l}\text { Melakukan pencatatan pengeluaran keuangan pada menu } \\
\text { anggaran spending }\end{array}$ \\
\hline F15 & Logout & $\begin{array}{l}\text { Melakukan logout untuk keluar dari aplikasi dengan memilih } \\
\text { menu logout pada tombol menu di menu utama }\end{array}$ \\
\hline
\end{tabular}

Skenario yang dibuat untuk acuan responden seperti pada Gambar 5 berikut:

\begin{tabular}{|c|c|}
\hline Task Fitur 1 & Registrasi \\
Skenario \\
Anda melihat iklan aplikasi cashoop pada browser anda, dan anda \\
tertarik untuk menjadi anggota cashoop ?
\end{tabular}

Gambar 5 Skenario Tugas

Dari skenario diatas menghasilkan chart diagram keberhasilan task sebagai berikut: 


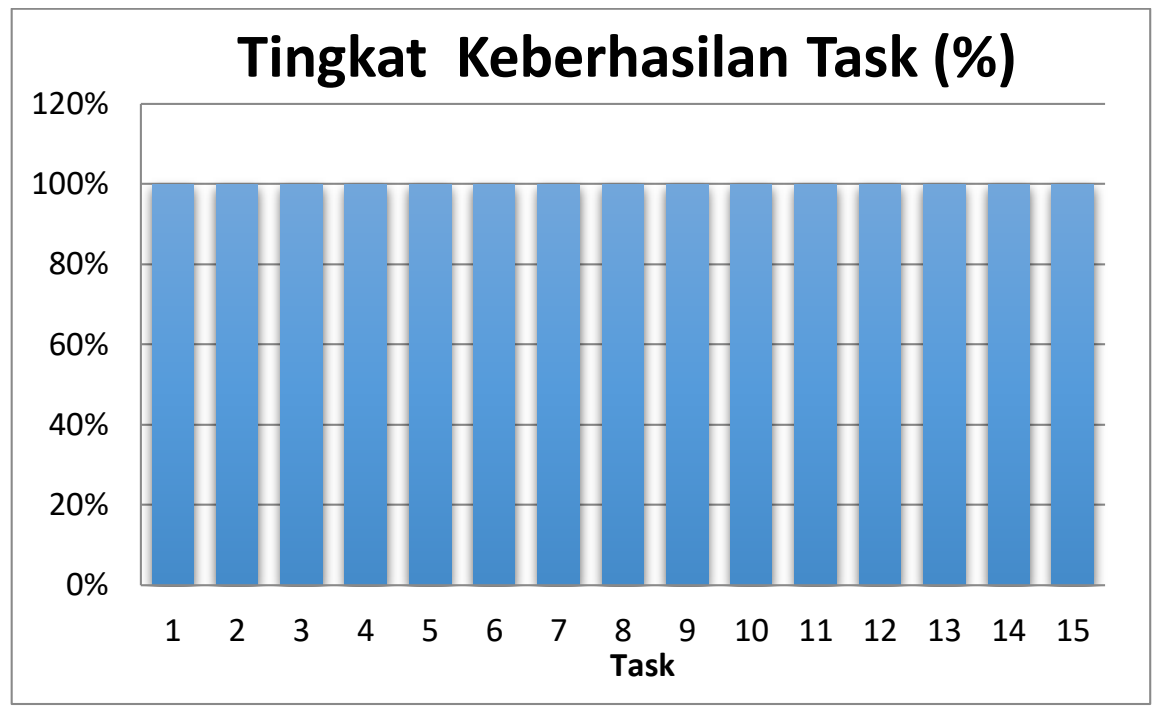

Gambar 6 Diagram Tingkat Keberhasilan Task

Semua task mempunyai tingkat keberhasilan 100\% atau hasilnya sama antara task 1 sampai 10. Skor ini belum dapat membantu dalam menarik kesimpulan, karena masih harus dilakukan benchmark. Benchmark yang umum dipakai adalah 78\% (Sauro, 2011)[6]. Artinya tingkat keberhasilan sebesar 100\% jika dibandingkan dengan benchmark $78 \%$ sudah di atas standar kebanyakan tingkat keberhasilan.

\section{Pengukuran Kemudahan}

Setelah menghitung tingkat keberhasilan selanjutnya melakukan pengukuran $S E Q$. Pengukuran $S E Q$ adalah pengukuran yang digunakan untuk mengukur sejauh mana kemudahan yang dirasakan pengguna setelah menyelesaikan setiap skenario/task yang diberikan.

Responden harus memilih ungkapan kemudahan tersebut dalam skala likert 7 poin yang disediakan di setiap akhir task/skenario yang diberikan bersamaan dengan pengukuran tingkat keberhasilan di atas.

Dari hasil rekapitulasi rata-rata $S E Q$ didapatkan chart diagram sebagai berikut:

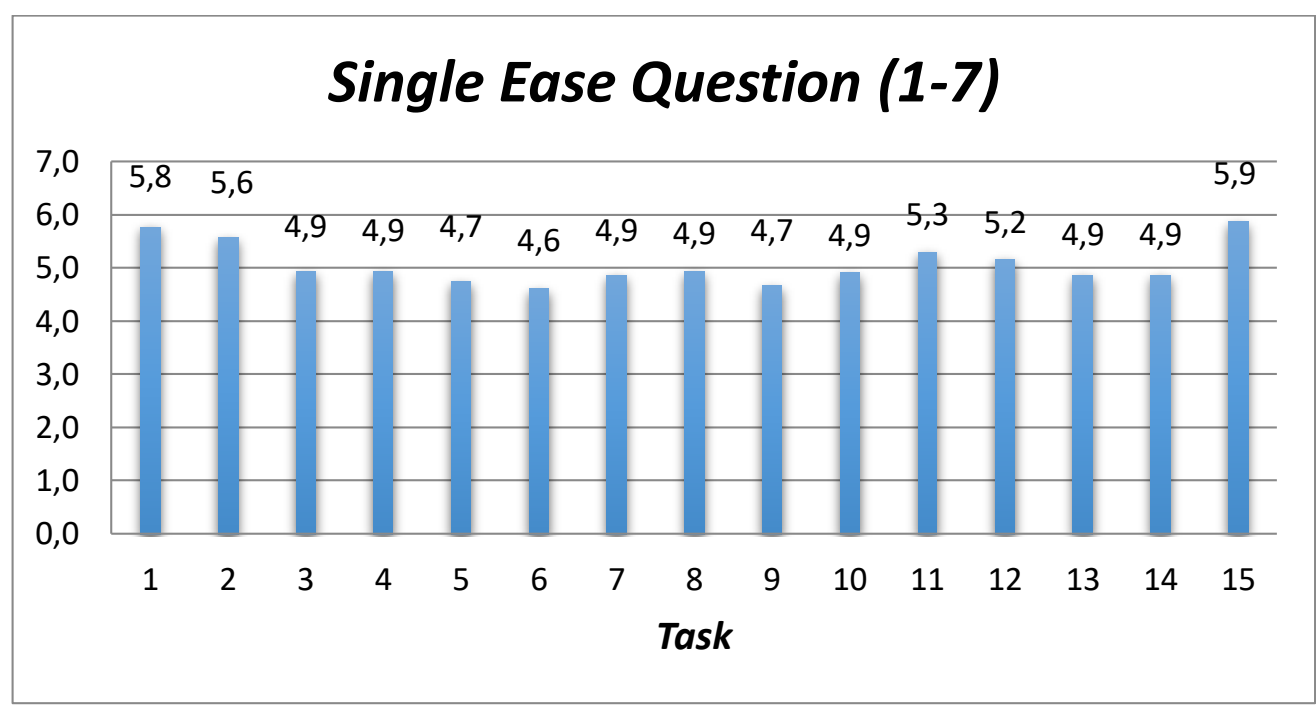

Gambar 7 Diagram $S E Q$ User

Diagram $S E Q$ pada gambar 7 menunjukan bahwa nilai $S E Q$ tertinggi adalah task 15 (logout) dan terendah adalah task 6 (hutang). Namun kesemuanya sudah berada di atas nilai rata-rata skor kesulitan. 
Rata - rata skor kesulitan $S E Q$ adalah 4,8 (Sauro, 2012)[7]. Artinys rata - rata skor $S E Q \quad \mathbf{5 , 1}$ jika dibandingkan dengan 4,8 sudah di atas rata-rata dan mudah digunakan.

\section{Pengukuran Efisiensi}

Efisiensi sebuah desain aplikasi yang diukur berdasarkan seberapa cepat sebuah aplikasi atau fitur digunakan. Pada penelitian ini digunakan satuan detik untuk mengukur kecepatan responden dalam mengerjakan task.

Teknik yang digunakan untuk mengukur waktu responden dalam mengerjakan task adalah stop watch pada handphone.

Dari hasil lama task user yang telah dilakukan didapat chart diagram sebagai berikut:

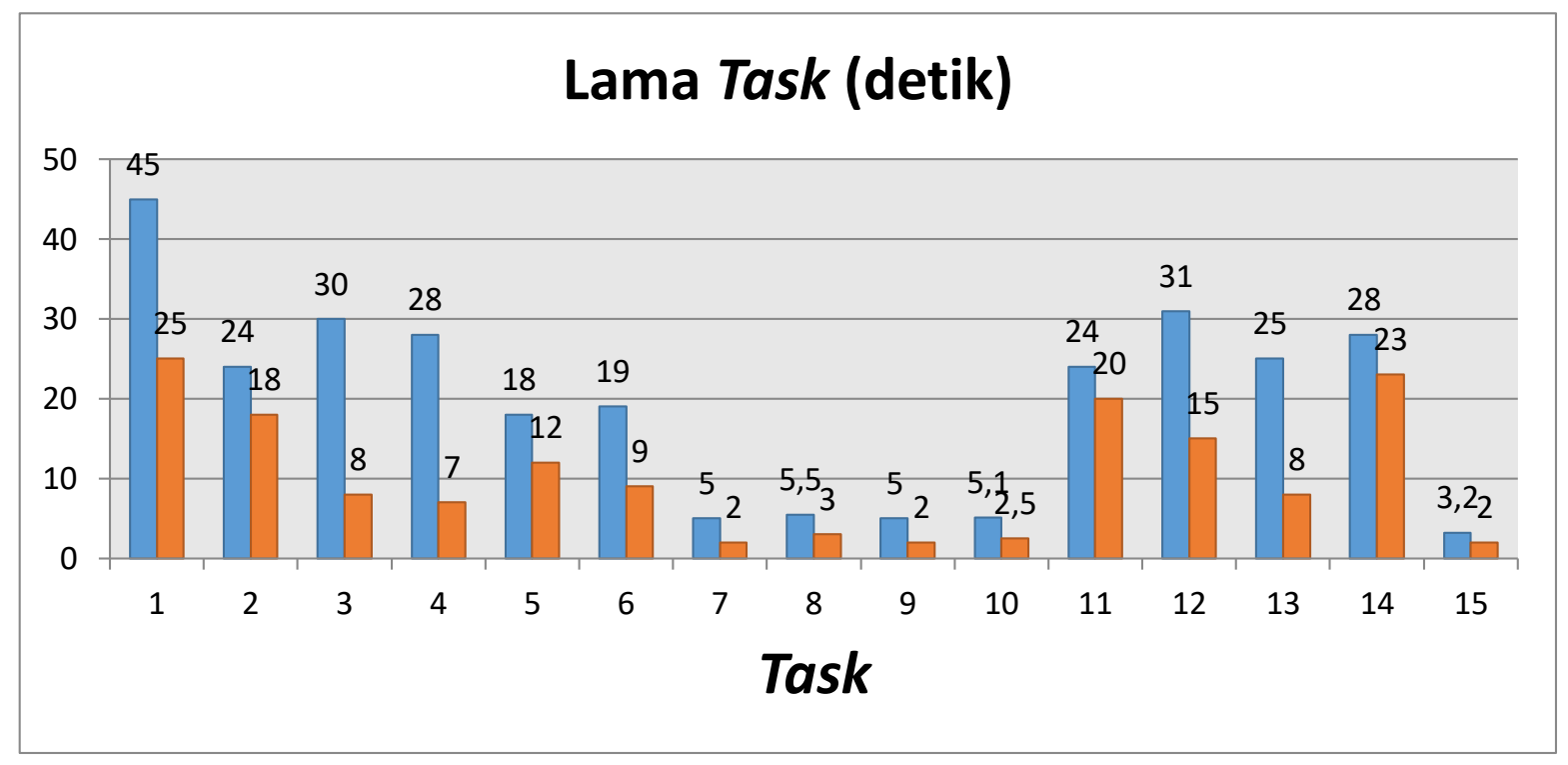

Gambar 8 Diagram Lama Task

Diagram pada gambar 8 menunjukkan lamanya responden mengerjakan task dibandingkan dengan pengguna ahli mengerjakan task. Pada task 1 dan 13 responden sedikit lebih lama karena pada task 1 responden harus menginputkan beberapa data untuk mendaftarkan sebagai anggota, sedangkan pada task 13 responden melakukan pencatatan anggaran untuk membayar hutang yang dimiliki. Hal ini tentu mempengaruhi seberapa cepat responden melakukan task karena inputan yang berbeda-beda. Dari diagram di atas secara keseluruhan dapat disimpulkan bahwa rata-rata responden dalam mengerjakan task tidak terlampau jauh signifikan dibandingkan dengan pengguna ahli.

\section{Pengukuran Kepuasan}

Setelah mendapatkan data efektifitas, efisiensi, dan post- skenario, maka tibalah pengukuran terhadap sistem aplikasi secara keseluruhan dengan menggunakan pengujian SUS ( Software Usability Scale). Pengujian dilakukan dengan memberikan kuisioner yang terdiri dari 10 item pertanyaan, dengan menggunakan skala likert 5 tingkat. Skala likert 5 ini jika dijabarkan sangat tidak setuju, tidak setuju, ragu-ragu, setuju dan sangat setuju. Item ganjil memiliki 5 pertanyaan positif dan item genap memiliki 5 pertanyaan negatif. Dengan kontribusi nilai dari masing-masing item pertanyaan adalah 0-4.

Dari perhitungan SUS yang telah didapat nilai rata-rata skor $S U S$ responden adalah 71,08 yang dapat dilihat pada diagram berikut 


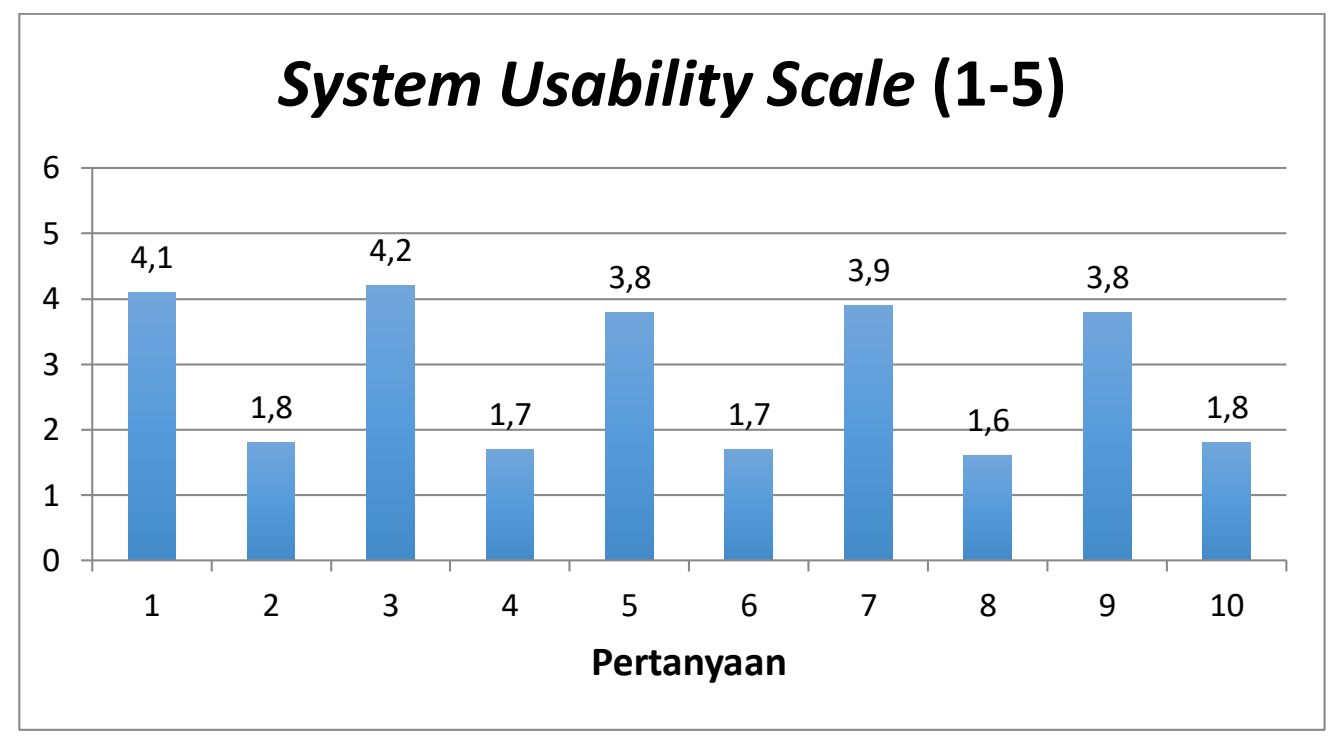

Gambar 9 Diagram SUS

Berdasarkan diagram pada gambar 9 nilai tertinggi didapatkan pada pertanyaan task 3 (pertanyaan positif) dan terendah pada task 8 (pertanyaan negatif).

\subsection{Analisis Hasil Pengujian}

Dari pengujian yang telah dilakukan menggunakan skenario post task yang disebar kepada 30 responden di dapatkan hasil sebagai berikut:

\section{SEQ (Single Ease Question)}

Hasil pengukuran $S E Q$ user yang telah dilakukan menujukkan bahwa nilai keseluruhan rata-rata skor $S E Q$ responden adalah 5,1 yang dapat dilihat pada gambar 5 diagram $S E Q$ diatas.

Pada gambar 5 diagram $S E Q$ diatas menunjukkan bahwa nilai $S E Q$ tertinggi adalah task 15 (logout) dan terendah adalah task 6 (hutang). Task 15 (logout) menjadi nilai tertinggi karena fungsi ini dianggap mudah oleh user dimana di fungsi ini user hanya mengerjakan perintah keluar dari aplikasi. Sedangkan pada task 6 (hutang) menjadi nilai terendah karena di fungsi ini user harus menginput data hutang, jenis hutang dan sisa pokok hutang yang di miliki.

Rata-rata skor kesulitan $S E Q$ menurut Sauro (2012) [7] adalah 4,8. Artinya rata-rata skor $S E Q$ 5,1 dari hasil pengujian yang telah dilakukan jika dibandingkan dengan 4,8 sudah berada diatas rata-rata dan mudah digunakan.

\section{SUS (System Usability Scale)}

Hasil perhitungan SUS yang telah dilakukan menunjukkan bahwa secara keseluruhan nilai rata-rata skor SUS responden adalah 71,08 yang dapat dilihat pada gambar 7 diagram SUS diatas.

Pada gambar 7 diagram SUS diatas menunjukkan bahwa nilai tertinggi didapatkan pada pertanyaan task 3 (pertanyaan positif) dan terendah pada pertanyaan task 8 (pertanyaan negatif). Pertanyaan task 3 (pertanyaan positif) menjadi nilai tertinggi karena pada pertanyaan ini rata-rata user setuju bahwa aplikasi ini mudah digunakan, sedangkan pada pertanyaan task 8 (pertanyaan negatif) menjadi nilai terendah karena rata-rata user tidak setuju kalau aplikasi ini sulit untuk digunakan.

Rata-rata skor SUS menurut Sauro (2012) [7] adalah 68. Artinya bahwa nilai rata-rata perhitungan SUS 71,08 dari hasil penghitungan yang telah dilakukan jika dibandingkan dengan 68 maka 71,08 dinyatakan diatas rata-rata.

Menurut Bangor et al (2009)[8], penilaian berdasarkan skor akhir SUS menggunakan tiga kategori yaitu Not Acceptable dengan rentang skor SUS 0-50.9, Marginal 51-70.9, dan Acceptable 71-100 
(Bangor et al., 2009)[8]. Dari perhitungan SUS diatas, dapat disimpulkan bahwa nilai rata - rata responden adalah 71,08 maka dinyatakan Acceptable.

\section{Kesimpulan dan Saran}

\subsection{Kesimpulan}

Berdasarkan hasil penelitian yang telah dilakukan dapat disimpulkan bahwa:

1. Pengembangan user interface dan user experience aplikasi cashoop yang dikembangkan sesuai dengan pengujian usability yang telah dilakukan melalui pengujian post task dan post study dengan hasil:

a. Pengukuran efektifitas dengan tingkat keberhasilan $\mathbf{1 0 0 \%}$.

b. Pengukuran kemudahan dengan skor $S E Q$ responden $\mathbf{5 , 1}$.

c. Pengukuran efisiensi dengan nilai rata-rata lama task responden $\mathbf{1 9 , 7 2}$ dan nilai pengguna ahli $\mathbf{1 0 , 4 3 .}$

d. Pengukuran kepuasan dengan nilai $S U S$ responden 71,08.

2. Pengembangan user interface dan user experience aplikasi cashoop ini sudah dapat diterima oleh pengguna dengan melihat hasil pengujian usability yang telah dilakukan.

\subsection{Saran}

Saran yang dapat diberikan sehubungan dengan user interface dan user experience aplikasi cashoop yang telah dikembangkan adalah sebagai berikut:

1. Pada task 6 (hutang) pengujian $S E Q$ user menjadi nilai terendah dikarenakan di fungsi ini user harus menginput data hutang, jenis hutang, sisa pokok hutang serta user juga harus mengingat hutang yang mereka miliki. Efektifnya user harus selalu mencatat hutang yang mereka lakukan, agar saat menginput data hutang yang dimiliki ke dalam aplikasi tidak membutuhkan yang waktu lama.

2. Pengukuran lama waktu responden dan pengguna ahli mengerjakan task dalam task 1 dan 13 sedikit lebih lama dibandingkan dengan task yang lain. Pada task 1 responden harus menginputkan beberapa data untuk mendaftarkan diri sebagai anggota, sedangkan pada task 13 responden melakukan pencatatan anggaran untuk membayar hutang serta harus mengingat hutang yang mereka miliki. Efektifnya responden harus selalu mencatat anggaran biaya bayar tiap hutang yang telah dilakukan.

3. Pada task 2 pengujian SUS menjadi nilai tertinggi dikarenakan rata-rata responden melihat ada bagian fitur aplikasi yang cukup merepotkan dan pada task 10 rata-rata responden merasa harus belajar banyak hal terlebih dahulu sebelum menggunakan aplikasi. Semestinya hal ini tidak akan terjadi jika tersedia buku panduan cara menggunakan aplikasi untuk user.

4. Pada task 5 pengujian SUS menjadi nilai terendah dikarenakan rata-rata responden kurang setuju apabila fitur pada aplikasi ini sudah terintegrasi dengan baik satu sama lain dengan nilai 3,8 dan pada task 9 rata-rata responden kurang merasa mantap menggunakan aplikasi ini dengan nilai 3,8. Nilai 3,8 ini masih termasuk dalam skala likert 3 yang artinya nilai sudah diatas ragu-ragu tetapi belum mendekati setuju. Semestinya responden tidak perlu ragu-ragu apabila responden dari aplikasi ini adalah orang-orang yang mengerti tentang teknologi serta paham akan pengelolaan keuangan bukan orang-orang yang hanya sekedar tahu teknologi tetapi kurang begitu memahaminya.

5. Aplikasi dapat dikembangkan dengan menambahkan fitur-fitur lain yang berhubungan dengan rencana keluarga di masa depan, seperti rencana anggaran keuangan untuk sekolah anak dari paud sampai kuliah.

6. Tambahkan notifikasi sisa keuangan bulan sebelumnya pada menu utama agar dapat terlihat sisa keuangan bulan sebelumnya pada bulan selanjutnya.

\section{Daftar Pustaka}

[1] Ardiansyah (2012). Analisis Pengambilan Keputusan Berbasis Personal Finance Information Systems, Seminar Nasional Teknologi Informasi dan Komputasi (SENASTIK) Program Studi 
Informatika Universitas Trunojoyo Madura, 13-14 November 2012. pp. SI.141-SI.147. ISSN 2302-7088

[2] Ardiansyah, \& Sujatmiko, A. (2007). MyFamily Accounting. Indonesia: Dirjen HKI Kemenhukam RI.

[3] Rochim, A. N., Hasbi, M., Irawati, T. (2011), Aplikasi Pengelolaan keuangan pada PT. Jala Prokreasi Surakarta, Surakarta: Sinus

[4] Galitz, WO. 2002. The Essential Guide To User Interface Design: An Introduction To GUI Design Principle and Techniques. Ed ke-2. John Willey \& Sons, Inc, Canada.

[5] Garret, James.J. 2011. The Eements of User Experience: User-Centered Design for the Web and Beyond. Ed ke-2. New Riders Publishing, United State of America.

[6] Sauro, jeff. 2011. Measuring Usability with the System Usability Scale (SUS). Available at: http://www.measuring.com/sus/. [15 Maret 2017]

[7] Sauro, J, \& Lewis, J. R (2012). Quantifying the User Experience: Practical Statistics User Research. (S. Elliot, Ed.) (I.). USA: Elsevier.

[8] Bangor, A., Kortum, P ., \& Miller, J. (2009). Determining What Individual SUS Scores Mean : Adding an Adjective Rating Scale. Journal of Usability Studies, 4(3), 114-123. 